\title{
Breast-related effects of selective estrogen receptor modulators and tissue-selective estrogen complexes
}

\author{
Carolyn L Smith ${ }^{1}$, Richard J Santen ${ }^{2}$, Barry Komm³ and Sebastian Mirkin ${ }^{3 *}$
}

\begin{abstract}
A number of available treatments provide relief of menopausal symptoms and prevention of postmenopausal osteoporosis. However, as breast safety is a major concern, new options are needed, particularly agents with an improved mammary safety profile. Results from several large randomized and observational studies have shown an association between hormone therapy, particularly combined estrogen-progestin therapy, and a small increased risk of breast cancer and breast pain or tenderness. In addition, progestin-containing hormone therapy has been shown to increase mammographic breast density, which is an important risk factor for breast cancer. Selective estrogen receptor modulators (SERMs) provide bone protection, are generally well tolerated, and have demonstrated reductions in breast cancer risk, but do not relieve menopausal symptoms (that is, vasomotor symptoms). Tissue-selective estrogen complexes (TSECs) pair a SERM with one or more estrogens and aim to blend the positive effects of the components to provide relief of menopausal symptoms and prevention of postmenopausal osteoporosis without stimulating the breast or endometrium. One TSEC combination pairing conjugated estrogens (CES) with the SERM bazedoxifene (BZA) has completed clinical development and is now available as an alternative option for menopausal therapy. Preclinical evidence suggests that CE/BZA induces inhibitory effects on breast tissue, and phase 3 clinical studies suggest breast neutrality, with no increases seen in breast tenderness, breast density, or cancer. In non-hysterectomized postmenopausal women, CE/BZA was associated with increased bone mineral density and relief of menopausal symptoms, along with endometrial safety. Taken together, these results support the potential of CE/BZA for the relief of menopausal symptoms and prevention of postmenopausal osteoporosis combined with breast and endometrial safety.
\end{abstract}

\section{Introduction}

Vasomotor symptoms (VMSs) occur in up to $88 \%$ of women during the early years of menopause [1], and vulvar-vaginal atrophy (VVA) symptoms (for example, vaginal dryness, irritation, soreness, and dyspareunia) are reported by up to $50 \%$ of postmenopausal women [2]. Women also lose bone mineral density (BMD) after menopause, leading to increased risk of osteoporosis and fractures $[3,4]$.

Hormone therapy (HT) comprises estrogen therapy (ET) for hysterectomized women and estrogen-progestin therapy (EPT) for women with a uterus. Although ET and EPT effectively treat VMS and VVA and prevent postmenopausal osteoporosis [5], some regimens are

\footnotetext{
* Correspondence: sebastian.mirkin@pfizer.com

${ }^{3}$ Pfizer Inc, 500 Arcola Road, Collegeville, PA 19426, USA

Full list of author information is available at the end of the article
}

associated with breast safety and tolerability issues [6-8]. Other approved agents for prevention or treatment of postmenopausal osteoporosis - that is, raloxifene (RLX), bisphosphonates, calcitonin, parathyroid hormone, and denosumab - do not relieve menopausal symptoms.

Tissue-selective estrogen complexes (TSECs), which combine a selective estrogen receptor modulator (SERM) with one or more estrogens, represent a new therapeutic approach. This strategy aims to relieve menopausal symptoms and prevent postmenopausal osteoporosis without negatively impacting breast and endometrial safety. The recently approved TSEC pairing conjugated estrogens (CEs) with bazedoxifene (BZA) was evaluated in a series of phase 3 clinical trials in postmenopausal women [9-20]. A key issue is whether TSECs exert estrogenic or anti-estrogenic effects on the breast. This review

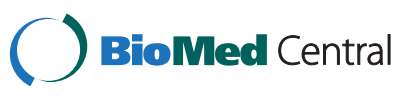

(c) 2014 Smith et al.; licensee BioMed Central Ltd. The licensee has exclusive rights to distribute this article, in any medium, for 6 months following its publication. After this time, the article is available under the terms of the Creative Commons Attribution License (http://creativecommons.org/licenses/by/2.0), which permits unrestricted use, distribution, and reproduction in any medium, provided the original work is properly cited. 
summarizes the breast-related effects of HT, SERMs, and TSECs in postmenopausal women.

\section{Breast-related effects of estrogen therapy}

In clinical settings, HT has been associated with breast safety issues, including a potential increase in breast cancer $[6,8]$, increased mammographic breast density [21,22], and breast pain or tenderness [7]. Breast cancer risk appears to be greater with EPT than ET. The randomized, placebo-controlled Women's Health Initiative (WHI) study initially reported a lower risk of invasive breast cancer after a mean of 6.8 years of ET (specifically CE) use (hazard ratio (HR) 0.77, 95\% CI 0.57 to 1.06; $P=0.06$ ), with separation of the Kaplan-Meier curves beginning at 2 years [23]. Despite early termination of the trial and discontinuation of ET by more than $90 \%$ of participants, reduction in breast cancer risk among those originally randomly assigned to ET persisted and became statistically significant during continued followup (HR $0.77,95 \%$ CI 0.62 to $0.95 ; P=0.02$ at a median of 10.7 years of follow-up), and mortality among those with breast cancer was also reduced in the ET group (HR 0.62, 95\% CI 0.39 to $0.97 ; P=0.04$ ) [24]. In contrast, the parallel, randomized, placebo-controlled WHI study of EPT found it to be associated with an increased risk of invasive breast cancer (HR 1.24, 95\% CI 1.01 to $1.54 ; P=$ 0.003 ) at study termination (mean of 5.6 years) [8], which persisted in the postintervention period (HR 1.25, 95\% CI 1.07 to $1.46 ; P=0.004$ at a mean of 11.0 years of follow-up) [25]. Furthermore, the WHI study found an increased risk of breast-cancer related mortality in the EPT group at long-term follow-up (HR 1.96, 95\% CI 1.00 to $4.04 ; P=0.049$ ) [25].

The exact mechanism for an association between estrogens and breast cancer risk is not fully understood. One hypothesis argues that binding of estrogens to estrogen receptors (ERs) stimulates cellular proliferation, which increases the likelihood that DNA damage will be propagated during cell division, ultimately leading to breast carcinogenesis [26]. Another hypothesis is that estrogens are not oncogenic but promote existing occult tumors [27]. A third suggests that estrogen metabolites such as the catechol estrogens interact with DNA directly and have a carcinogenic effect in the breast [28].

Different types of estrogens may exhibit different estrogenic effects in breast tissue. For example, in a study comparing $\mathrm{CE}$ and estradiol on the growth and proliferation of MCF-7 breast cancer cells in vitro, estradiol was approximately 10 times more potent than $\mathrm{CE}$ for stimulating MCF-7 breast cancer overall cell growth and cellular proliferation [29]. In addition, estradiol inhibited apoptosis at a lower concentration than $\mathrm{CE}$ and, in gene expression studies, stimulated the expression of progesterone receptor $(\mathrm{PR})$ and amphiregulin to a greater extent than
CE [29]. In a separate study evaluating estradiol and CE on the growth of MCF-7 xenografts in a mouse model, estradiol - but not CE - stimulated tumor growth [30]. Estradiol also induced higher expression of a number of known ER target genes than did CE, which exhibited only weak estrogenic activity [30].

Despite progesterone's anti-proliferative effects on the endometrium, it has been shown to have proliferative effects in the breast, independent of estrogen [31]. Preclinical data suggest a number of mechanisms by which progestins may increase breast cancer risk. One hypothesis is that progestogens activate the stem cell pool and accelerate tumor formation in the breast or that they convert some $\mathrm{PR}^{+}$cells into basal $\mathrm{ER}^{-} / \mathrm{PR}^{-}$stem cell-like cells [32]. The estrogen component of EPT may restore PR expression (which declines during postmenopause), allowing stimulation and amplification by the progestin component of these previously dormant stem cells [32]. In addition, progestins have been shown to stimulate production of vascular endothelial growth factor and therefore may promote tumor angiogenesis [33]. Recent studies have implicated progesterone in breast cancer cell proliferation through intracellular signaling via the PR and its various downstream targets and effectors [34,35]. There is also evidence that progestin-activated PR signaling leads to downregulation of the microRNA miR-16, a potent suppressor of breast cancer cell growth and proliferation [36]. Finally, there is evidence that progestins increase angiogenesis and decrease apoptosis via differential regulation of fibroblast growth factors, independent of PR signaling [37].

Increased mammographic breast density is a significant risk factor for breast cancer development [38,39], and high mammographic breast density may decrease sensitivity for detecting breast abnormalities [40]. Newonset breast tenderness occurs significantly more frequently in women receiving combined EPT compared with placebo or CE alone [41] and is associated with increased mammographic breast density [21] and subsequent breast cancer risk [41].

\section{Breast-related effects of selective estrogen receptor modulators}

SERMs are structurally diverse compounds that differ chemically from each other as well as from estrogens (Figure 1). Like estrogens, SERMs bind to the ER; however, whereas estrogens are ER agonists, SERMs exhibit selective agonist and antagonist effects depending on the target tissue [42]. After an individual SERM binds to the ER, the SERM-ER complex adopts a unique conformation (Figure 2) that may result in a distinctive pattern of cofactor recruitment [43]. Each SERM's activity is derived from its unique ability to direct the structure of the receptor's ligand-binding domain and consequently 


\section{Estrogens}
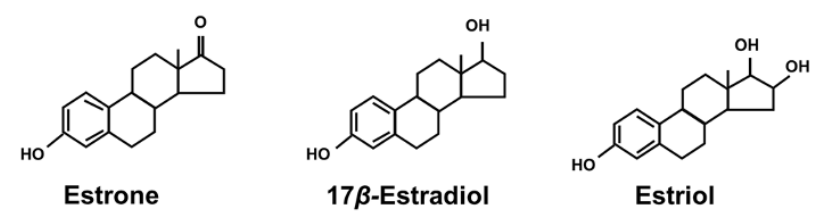

SERMs
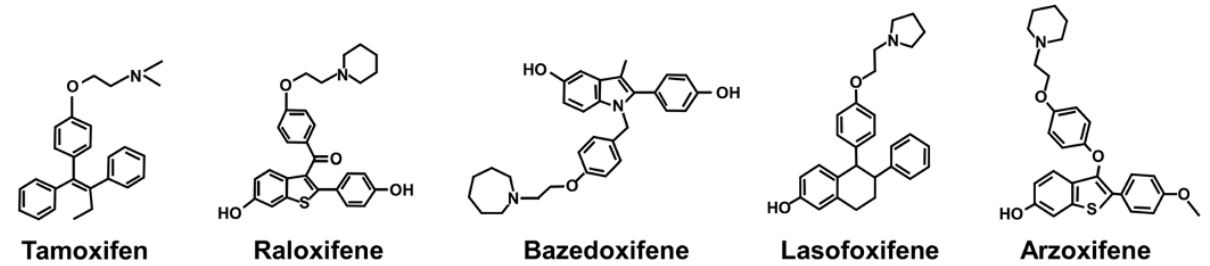

Figure 1 Structural diversity of estrogens and selective estrogen receptor modulators (SERMs). A chemically diverse group of SERMs and estrogens all function by binding to estrogen receptors.

its interaction with coactivators or corepressors, resulting in cell- and tissue-specific alterations in gene expression [43]. Tamoxifen and RLX were initially classified as anti-estrogens that inhibited estrogen's stimulatory actions in breast cancer cells [44]. However, early studies revealed that these agents could exhibit agonist or antagonist activities in different tissues, resulting in their reclassification as SERMs [44-46]. For example, although tamoxifen showed anti-estrogenic activity in the treatment and prevention of breast cancer, it also demonstrated estrogen agonist activity with its boneprotective and endometrial-stimulatory effects $[47,48]$. The mechanistic insights gained from studies of tamoxifen and RLX prompted the development of second- and third-generation SERMs, such as lasofoxifene (LAS), BZA, arzoxifene, and ospemifene [49]. Like tamoxifen, arzoxifene has been associated with positive bone effects and prevention of $\mathrm{ER}^{+}$breast cancer but also stimulation

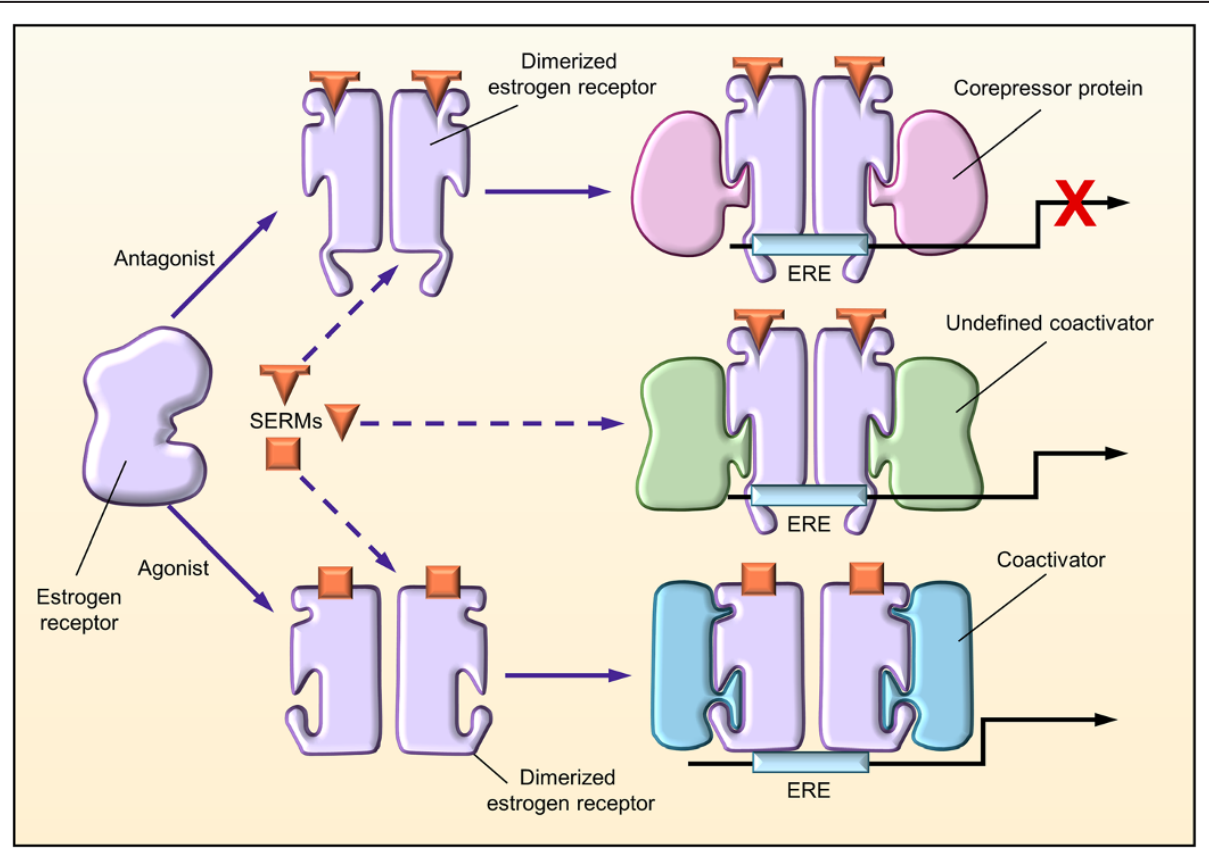

Figure 2 Molecular activity of selective estrogen receptor modulators (SERMs) at estrogen receptors. When a SERM binds to the estrogen receptor, the receptor adopts a unique conformation that allows dimerization and interaction with estrogen response elements (EREs) of the target genes. The unique conformational change induced by binding of the SERM may result in a distinct pattern of cofactor recruitment. Reprinted with permission from Elsevier [43]. 
of the endometrium [50-52], whereas ospemifene is indicated only for the treatment of moderate to severe dyspareunia, a symptom of VVA, due to menopause [53]. The impact of the other SERMs on the breast is discussed below.

\section{Tamoxifen}

Tamoxifen, which has been in clinical use for approximately 40 years, is approved by the US Food and Drug Administration for treatment of metastatic breast cancer, adjuvant treatment of node-positive and axillary nodenegative breast cancer, ductal carcinoma in situ, and breast cancer risk reduction in women at high risk [54]. Preclinical results demonstrated inhibitory effects of tamoxifen on growth of $\mathrm{ER}^{+}$tumors [55,56], and an extensive body of clinical evidence supports the efficacy of tamoxifen in treatment and risk reduction of breast cancer [57]. Tamoxifen is associated with a reduction in breast density [58], which has been positively associated with reduced breast cancer risk [59]. For example, Cuzick and colleagues [59] showed that tamoxifentreated patients with a reduction in breast density of at least $10 \%$ experienced a $63 \%$ reduction in breast cancer risk (odds ratio 0.37, 95\% CI 0.20 to 0.69 ) but that tamoxifen-treated patients with a reduction in breast density of less than $10 \%$ showed no risk reduction. Although many of its effects are beneficial, tamoxifen has been associated with an increased risk of thromboembolic events and endometrial cancer, which has led to a search for alternative agents for treatment and prevention of breast cancer [57].

\section{Raloxifene}

RLX is approved for prevention and treatment of postmenopausal osteoporosis and for reduction in risk of invasive breast cancer in postmenopausal women with osteoporosis or at high risk for invasive breast cancer [60]. In preclinical studies, RLX did not promote the proliferation of MCF-7 breast cells [61,62]. A study by Lewis-Wambi and colleagues [63] compared the effects of BZA, 4-hydroxytamoxifen, endoxifen, RLX, and fulvestrant (a pure anti-estrogen) on the growth of hormone-dependent and hormone-independent MCF-7 breast cancer cell lines. RLX inhibited estrogenstimulated breast cancer cell proliferation but did not inhibit proliferation of hormone-independent breast cancer cells. RLX is generally an ER antagonist in breast tissue; however, RLX may stimulate expression of certain ER genes. For example, in ovariectomized (OVX) mice, RLX upregulated expression of the mammary gland expression marker indoleamine-pyrrole 2,3 dioxygenase compared with vehicle control, which is indicative of ER agonist activity [64]. Nonetheless, clinical studies consistently show a reduced incidence of breast cancer in women receiving RLX [65-68]. For example, in the randomized, double-blind, Multiple Outcomes of Raloxifene Evaluation (MORE) trial of postmenopausal women with osteoporosis $(n=7,705)$, RLX decreased the risk of invasive breast cancer by $72 \%$ over 4 years compared with placebo (PBO) (relative risk (RR) $0.28,95 \%$ CI 0.17 to 0.46) [65]. In the 4-year Continuing Outcomes Relevant to Evista (CORE) extension of the MORE study ( $\mathrm{n}=$ 4,011 ), reduced risk of invasive breast cancer by RLX was maintained versus $\mathrm{PBO}$ (HR 0.41, 95\% CI 0.24 to 0.71 ) [66]. At long-term follow-up $(n=19,490)$ of the randomized, double-blind Study of Tamoxifen and Raloxifene trial, RLX was less effective than tamoxifen for prevention of invasive breast cancer (RR 1.24, 95\% CI 1.05 to 1.47) and ductal carcinoma in situ (RR 1.22, 95\% CI 0.88 to 1.69) [68]. The incidence of breast pain was similar with RLX and PBO in the MORE [65] and CORE [66] studies, but in the Euralox-1 study of healthy postmenopausal women $(n=1,008)$, the incidence of breast pain was significantly lower with RLX than with HT $(1.8 \%$ versus $26.5 \%$, respectively; $P<0.001$ ) [69]. A recent review concluded that RLX did not increase or decrease mammographic breast density [70]; however, many of the studies assessing the effect of RLX on breast density have been relatively small (fewer than 200 patients), and methods of measuring breast density have not been consistent [71-73].

\section{Lasofoxifene}

LAS was developed for treatment of vaginal atrophy and prevention and treatment of postmenopausal osteoporosis [74]. LAS exhibited anti-proliferative effects in estrogen-sensitive MCF-7 breast cancer cells $[62,75]$ and did not change the histology of mammary tissue in OVX cynomolgus macaques [76]. The 5-year Postmenopausal Evaluation and Risk-reduction with Lasofoxifene study $(\mathrm{n}=8,556)$ demonstrated an $81 \%$ reduction in risk of total $\mathrm{ER}^{+}$breast cancer and an $83 \%$ reduction in risk of invasive $\mathrm{ER}^{+}$breast cancer with LAS $0.5 \mathrm{mg} /$ day versus PBO $(P<0.001)$ [77]. Pooled results from two identical phase 3 studies of varying doses of LAS in postmenopausal women $(n=1,907)$ showed no increase in breast density or breast pain with LAS versus PBO [78]. LAS received European Union (EU) marketing authorization from the European Commission in 2009. A series of industry acquisitions, asset shifts, and licensing of product rights has since ensued, delaying its launch. Since LAS did not become commercially available within 3 years, its EU approval has lapsed but may be reapplied for eventually or it may become available as an unlicensed medicinal product available by physician request for patients who are not candidates for approved therapies $[79,80]$. 


\section{Bazedoxifene}

BZA is a newer-generation SERM that has demonstrated efficacy for the prevention and treatment of postmenopausal osteoporosis [81,82]. Its development was prompted by the need for improved SERMs that could protect the skeleton, improve lipid profile, reduce hot flush frequency and severity, reduce vaginal dryness and atrophy, and maintain bladder function without stimulating the endometrium or breast [83]. During preclinical development, BZA was shown to be a functionally active ER ligand with beneficial effects on bone and total cholesterol, antagonist activity in the breast, and neutral effects on the endometrium; however, it did not inhibit vasomotor response when given at a bone-protective dose [83]. Although a discussion of the full range of effects of BZA and other SERMs is beyond the scope of this article, a review of this topic was recently published [84], as was a review of the differential effects of menopausal therapies on the endometrium [85].

Further preclinical investigations confirmed that BZA acts as an estrogen antagonist in the breast. In MCF-7 proliferation assays, BZA did not stimulate cell proliferation and potently inhibited estradiol-stimulated proliferation [61]. In the previously described study by Lewis-Wambi and colleagues [63], all of the compounds studied inhibited estradiol-stimulated breast cancer cell proliferation, but only BZA and fulvestrant significantly inhibited the growth of hormone-independent MCF-7:5C cells [63]. Growth inhibition of MCF-7:5C with BZA was associated with cell cycle arrest and downregulation of cyclin D1 and ER $\alpha$ [63]. In a separate study evaluating the effects of BZA on the growth of breast cancer xenografts in mouse models, BZA inhibited the growth of tamoxifen-sensitive and tamoxifen-resistant tumor xenografts [86]. Unlike other SERMs, BZA downregulates ER expression and therefore shares some properties of selective estrogen receptor degraders, such as the pure anti-estrogen fulvestrant [86]. The extent to which this contributes to growth inhibition of tumor xenografts is unclear, but BZA exhibits antagonist activity in breast cancer cells in vitro independent of ER degradation [86].

BZA's lack of ER-stimulatory activity in the breast is reinforced by data from phase 3 , randomized, doubleblind studies in postmenopausal women [87-89]; however, these studies were not sufficiently powered to detect breast cancer prevention. In a 2-year trial of varying doses of BZA, RLX $60 \mathrm{mg}$, and PBO in healthy postmenopausal women at risk for osteoporosis $(n=1,583)$, rates of breast carcinoma ( $0 \%$ to $0.6 \%$ ) and breast pain (2.6\% to $3.7 \%$ ) were low and similar among treatment groups [87]. A phase 3, randomized, double-blind, 3year trial of BZA (20 or $40 \mathrm{mg}$ ), RLX $60 \mathrm{mg}$, or PBO in women with osteoporosis $(n=7,492)$ showed no significant difference in the incidence of breast carcinoma and breast cysts with BZA compared with PBO or RLX; however, there was a significantly lower incidence of fibrocystic breast disease with BZA 20 or $40 \mathrm{mg}(0.3 \%$ and $0.2 \%$, respectively) versus $\operatorname{RLX}(0.8 \%$; both $P \leq 0.05)$ $[88,89]$. Breast pain incidence was similar among groups, with rates ranging from $2.4 \%$ to $3.0 \%[88,89]$. In a retrospective ancillary analysis of a subset of women $(n=444)$ from this study, mean percentage changes in breast density from baseline were low and similar among groups [90]. Consistent with the 3-year results, BZA showed a neutral effect on the breast at 5 years [91] and 7 years [92] of therapy.

\section{Breast-related effects of the tissue-selective estrogen complex}

As described above, SERMs are generally well tolerated and have not been shown to stimulate the breast. However, no SERM alone achieves an optimal balance of providing ER agonist activity to relieve menopausal symptoms and prevent bone loss while exerting antagonist effects on the breast. By pairing a SERM with one or more estrogens, the TSEC blends estrogenic properties with the tissue-selective activity of a SERM [93] with the goals of relieving menopausal symptoms and preventing bone loss while minimizing estrogenic effects on the endometrium and breast [93]. In comparison with EPT, a more favorable breast safety profile was expected for TSECs given the lack of a progestogen component, which (as noted above) has been associated with an increased risk of breast cancer compared with estrogens alone [94].

Molecular activity of the TSEC components at the receptor level may help explain differences in their activity compared with that of individual estrogens and SERMs. With a TSEC, competition of the SERM and estrogen components for binding to ERs is expected to result in unique combinations of ERs with conformations reflecting both SERM and estrogens. Furthermore, since SERMs and estrogens both bind to ERs, it is possible that their combination facilitates formation of novel receptor dimers that bind to both SERMs and estrogens rather than one or the other. Results of a recent study support the cooperative interaction of SERMs and estrogens through a heterodimeric complex [95]. Using an in vitro reporter gene assay, the cooperative control of gene expression by ER agonists (for example, CE and $17 \beta$-estradiol) and antagonists (for example, tamoxifen, RLX, BZA, and fulvestrant) was shown to be mediated through an ER heteroligand dimer complex, in which the ER agonist binds to one dimer subunit and the antagonist binds to the other [95]. The actions of TSEC within a given cell type may also reflect the net effect of TSECs on both receptor and cell environment integrated at the level of gene expression (for example, estrogens 
may modify the activity or expression of a cofactor that could promote SERM activity and vice versa) [96].

\section{Preclinical comparisons of different tissue-selective estro- gen complexes}

The breast-related effects of different TSECs, combining RLX, LAS, or BZA with one or more estrogens, have been evaluated in preclinical studies (Table 1) [30,62,64,97-99].

\section{In vitro studies}

Berrodin and colleagues [97] evaluated the effects of BZA, RLX, and LAS on CE-mediated recruitment of 43 cofactor peptides to the ER $\alpha$-ligand-binding domain by a multiplex biochemical assay. LAS and RLX in combination with $\mathrm{CE}$ completely inhibited the CE-mediated recruitment of all peptides [97]. In contrast, BZA in combination with $\mathrm{CE}$ inhibited the $\mathrm{CE}$-mediated recruitment of some, but not all, of the evaluated cofactor peptides, indicating the potential for tissue selectivity with $\mathrm{CE} / \mathrm{BZA}$ and suggesting that CE/BZA induces different conformations of ER $\alpha$ than either CE/RLX or CE/LAS [97]. The investigators also studied gene expression profiles in MCF-7 breast cancer cells and found that CE/BZA exhibited an expression profile for a subset of genes in the global gene expression profile that maintained some of the characteristics of CE alone, whereas CE/RLX and CE/LAS completely antagonized expression of this subset of CEregulated genes [97]. The CE-regulated genes antagonized by all three of these SERMs were involved in cell cycle regulation and cell-to-cell signaling [62,97]. Results from microarray studies comparing gene expression profiles of BZA, RLX, and LAS alone and in combination with CE in MCF-7 human breast cancer cells also supported a broad range of differences in gene expression patterns across the different SERM and TSEC combinations [62,96]. In an MCF-7 cell proliferation study, RLX, LAS, and BZA all significantly antagonized CE-stimulated proliferation of breast cancer cells; BZA exhibited similar or better efficacy at inhibiting MCF-7 cell growth than the other SERMs evaluated [62].

\section{In vivo studies}

Results of in vivo preclinical studies provide further evidence of differences in the activity of TSECs combining different SERMs with CE (Table 1) [64,98]. In the mammary gland of OVX mice, treatment with BZA and RLX (but not LAS), when given in combination with estradiol, reduced estradiol-induced mammary gland end bud proliferation [64]. In a separate study of the effects of BZA, RLX, and LAS alone and in combination with CE on mammary gland morphology in OVX sexually immature

Table 1 Preclinical results

\begin{tabular}{|c|c|c|}
\hline $\begin{array}{l}\text { Study } \\
\text { reference }\end{array}$ & Study design/model & Key results \\
\hline \multicolumn{3}{|l|}{ In vitro studies } \\
\hline \multirow[t]{3}{*}{$\begin{array}{l}\text { Berrodin et al. } \\
\text { [97] (2009) }\end{array}$} & \multirow[t]{3}{*}{$\begin{array}{l}\text { Multiplex ERa-cofactor peptide } \\
\text { interaction assay } \\
\text { GeneChip microarray }\end{array}$} & $\begin{array}{l}\text { LAS and RLX completely inhibited CE-mediated recruitment of all cofactor peptides to the } \\
\text { ERa-ligand-binding domain, whereas CE/BZA inhibited the CE-mediated recruitment of some, } \\
\text { but not all, peptides. }\end{array}$ \\
\hline & & CE/BZA gene expression profile was significantly different from CE/LAS or CE/RLX. \\
\hline & & $\begin{array}{l}\mathrm{CE} / \mathrm{RLX}, \mathrm{CE} / \mathrm{LAS} \text {, and CE/BZA antagonized genes involved in cell cycle regulation and growth } \\
\text { hormone signaling; CE/RLX and CE/LAS also antagonized expression of a set of CE-regulated } \\
\text { genes not affected by CE/BZA. }\end{array}$ \\
\hline \multirow{3}{*}{$\begin{array}{l}\text { Chang et al. } \\
\text { [62] (2010) }\end{array}$} & \multirow{3}{*}{$\begin{array}{l}\text { MCF-7 cell proliferation assays } \\
\text { GeneChip microarray }\end{array}$} & CE/RLX, CE/LAS, and CE/BZA all antagonized CE-stimulated proliferation, with antagonism levels \\
\hline & & 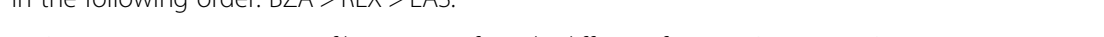 \\
\hline & & CE/BZA gene expression profile was significantly different from CE/LAS or CE/RLX. \\
\hline \multicolumn{3}{|l|}{ In vivo studies } \\
\hline \multirow{2}{*}{$\begin{array}{l}\text { Crabtree et al. } \\
\text { [64] (2008) }\end{array}$} & \multirow[t]{2}{*}{ Ovariectomized female mice } & BZA and RLX (not LAS) reduced estradiol-induced mammary gland end bud proliferation. \\
\hline & & $\begin{array}{l}\text { Estrogen-responsive marker studies in the mammary gland showed that BZA, RLX, and LAS all } \\
\text { function as ER antagonists but have different degrees of agonist activity. }\end{array}$ \\
\hline $\begin{array}{l}\text { Peano et al. } \\
\text { [98] (2009) }\end{array}$ & Ovariectomized mice & $\begin{array}{l}\text { BZA completely inhibited CE-induced increases in ductal tree branch points; RLX and LAS only } \\
\text { partially inhibited CE-induced effects. }\end{array}$ \\
\hline \multirow[t]{2}{*}{$\begin{array}{l}\text { Song et al. } \\
\text { [30] (2012) }\end{array}$} & \multirow{2}{*}{$\begin{array}{l}\text { Ovariectomized mice with } \\
\text { human MCF-7 breast cancer } \\
\text { xenografts }\end{array}$} & $\begin{array}{l}\text { BZA blocked the estrogenic effects of CE and estradiol (including ductal length, terminal end } \\
\text { bud development, proliferation, apoptosis, and gene expression changes). }\end{array}$ \\
\hline & & BZA inhibited estradiol-induced tumor growth and weight. \\
\hline \multirow[t]{2}{*}{$\begin{array}{l}\text { Ethun et al. } \\
\text { [99] (2012) }\end{array}$} & \multirow[t]{2}{*}{$\begin{array}{l}\text { Ovariectomized cynomolgus } \\
\text { monkeys }\end{array}$} & $\begin{array}{l}\text { CE/BZA antagonized CE-stimulatory effects on total breast epithelial density, Ki67 staining, markers } \\
\text { of ERa activity, and lobular size. }\end{array}$ \\
\hline & & BZA alone had neutral effects on all outcomes. \\
\hline
\end{tabular}


mice, BZA was the only SERM that completely inhibited CE-induced effects [98]. CE activity in the breast and uterus was antagonized by BZA to a greater extent than by RLX or LAS [98].

Overall, preclinical data support the concept that TSECs exhibit distinct pharmacologic profiles. In many tissues, BZA and CE exhibit opposite effects on shared ER target genes (for example, growth-related genes may be upregulated by estrogens and downregulated by BZA), whereas some genes (for example, FOS, CYR61, and $Z N F 10$ ) are regulated in the same direction by both BZA and CE [62]. These observations suggest that BZA selectively antagonizes certain aspects of $\mathrm{CE}$ action but may work in concert with $\mathrm{CE}$ at a subset of genes [62]. In contrast, results of gene expression profiling studies indicate that RLX or LAS in combination with CE antagonizes the expression of a greater number of CEregulated genes, which theoretically could limit CE's beneficial effects (for example, on vasomotor symptoms) [97]. Further preclinical and clinical data for CE/BZA, the only TSEC to complete clinical development, will be discussed below.

\section{Conjugated estrogens/bazedoxifene Additional preclinical data}

The breast safety profile of CE/BZA has been evaluated in murine and primate models $[30,99]$. In a study comparing estradiol, CE, and BZA, BZA blocked the estrogenic effects of $\mathrm{CE}$ or estradiol on ductal length, terminal end bud development, proliferation, apoptosis, and gene expression changes on mammary gland tissue and inhibited the growth and weight increase of tumors in human MCF-7 xenografts in OVX mice [30]. In the mammary gland of OVX cynomolgus macaques, CE stimulation of total breast epithelial density, Ki67 staining, markers of ER $\alpha$ activity, and lobular size were antagonized by treatment with CE/BZA [99]. On the basis of gene markers of cell proliferation or cell cycle progression, both BZA and CE/BZA lacked estrogen activity in the breast. The investigators suggested that ER $\alpha$ protein degradation may play a role in the inhibitory breast effects of BZA [99]. Along with the previously described results of comparative studies of $\mathrm{CE} / \mathrm{BZA}$ and other TSEC combinations, these results suggest that CE/BZA can antagonize estrogenic activity in normal and cancerous breast tissue.

\section{Clinical studies}

The efficacy and safety of CE/BZA were evaluated in the Selective estrogens, Menopause, And Response to Therapy (SMART) trials, five randomized, double-blind, placeboand active-controlled, phase 3 trials that enrolled postmenopausal women with a uterus (Table 2) [9-19,100-102]. Overall, the SMART trials demonstrated increased BMD and relief of VMS and VVA with CE/BZA treatment (Table 2) while ensuring endometrial safety and breast protection (Table 3). On the basis of these studies, CE $0.45 \mathrm{mg} / \mathrm{BZA} 20 \mathrm{mg}$ once daily was approved in 2013 by the US Food and Drug Administration for treatment of moderate to severe VMSs associated with menopause and for prevention of postmenopausal osteoporosis in women with a uterus [103].

\section{Breast safety outcomes from clinical studies}

The incidence of breast-related adverse events was low and similar for CE $0.45 \mathrm{mg} / \mathrm{BZA} 20 \mathrm{mg}$ compared with $\mathrm{PBO}$ in a pooled analysis of the SMART- 1 to -3 trials [104]. In SMART-1 $(n=3,397)$, the incidences of abnormal mammograms at 2 years were similar for $\mathrm{CE}$ $0.45 \mathrm{mg} / \mathrm{BZA} 20 \mathrm{mg}(4.4 \%)$ and PBO (2.6\%) [100]. Similarly, in SMART-5 (a placebo-controlled comparison of $\mathrm{CE} / \mathrm{BZA}$ and HT, $\mathrm{n}=1,843$ ), incidences of abnormal mammograms at 1 year were similar for CE $0.45 \mathrm{mg} / \mathrm{BZA}$ $20 \mathrm{mg}(0.9 \%)$ and PBO (0.2\%) [18].

Breast cancer rates were low across the SMART studies $[18,104]$, although it is important to note that these studies were not powered to demonstrate breast cancer prevention. In a pooled analysis of the SMART- 1 to -3 studies, the rate of breast cancer in the CE $0.45 \mathrm{mg} / \mathrm{BZA}$ $20 \mathrm{mg}$ group $(0.25 \%)$ was similar to that in the placebo group (0.17\%) [104].

CE/BZA does not appear to affect breast density. In an ancillary retrospective study of SMART-1 $(n=507)$, mean mammographic breast density changes at 2 years with CE $0.45 \mathrm{mg} / \mathrm{BZA} 20 \mathrm{mg}(-0.39 \%)$ were similar to those with PBO (-0.42\%) and RLX $60 \mathrm{mg}(-0.23 \%)$ [100]. Similarly, in the breast density substudy of SMART-5, CE $0.45 \mathrm{mg} / \mathrm{BZA} 20 \mathrm{mg}$ was not associated with increased breast density and demonstrated noninferiority compared with $\mathrm{PBO}$ at 12 months [18]. In contrast, CE $0.45 \mathrm{mg} /$ medroxyprogesterone acetate (MPA) $1.5 \mathrm{mg}$ was associated with a significant increase in breast density at 12 months versus PBO [18].

\section{Breast pain and tenderness outcomes from clinical studies}

There was no significant difference between the $\mathrm{CE}$ $0.45 \mathrm{mg} / \mathrm{BZA} 20 \mathrm{mg}$ and PBO groups in the percentage of women reporting breast pain or tenderness in any SMART trial $[10,13,15,17,18]$. In SMART-1 $(n=3,397)$, the incidence of breast pain among the CE/BZA, RLX, and PBO group was not significantly different [10]. In the SMART-2 $(\mathrm{n}=332)$, SMART-3 $\quad(\mathrm{n}=664)$, and SMART-4 $(\mathrm{n}=1,061)$ trials, there were no significant differences in the number of women reporting at least 1 day of breast pain between the CE/BZA and $\mathrm{PBO}$ groups $[13,15,17]$. In SMART-5 $(\mathrm{n}=1,843)$, the incidence of breast tenderness with $\mathrm{CE} / \mathrm{BZA}$ was similar to $\mathrm{PBO}$ and significantly lower than with CE/MPA $(P<0.001)$ 
Table 2 The SMART clinical trial program

\begin{tabular}{|c|c|c|c|c|c|c|}
\hline Study & Study design & Main inclusion criteria & $\begin{array}{l}\text { Number of } \\
\text { patients } \\
\text { randomly } \\
\text { assigned }\end{array}$ & $\begin{array}{l}\text { Treatment } \\
\text { groups }\end{array}$ & $\begin{array}{l}\text { Primary } \\
\text { endpoint }\end{array}$ & $\begin{array}{l}\text { Key } \\
\text { results }\end{array}$ \\
\hline \multirow[t]{14}{*}{$\begin{array}{l}\text { SMART-1 } \\
{[9-12,100]}\end{array}$} & \multirow[t]{14}{*}{$\begin{array}{l}\text { 2-year, } \\
\text { randomized, } \\
\text { double-blind, } \\
\text { multicenter, } \\
\text { placebo- and } \\
\text { active (RLX)-con- } \\
\text { trolled, phase } 3 \\
\text { trial }\end{array}$} & $\begin{array}{l}\text { Age } 40-75 \text { years } \\
\text { Postmenopausal } \\
\text { ( } \geq 12 \text { months } \\
\text { amenorrhea, } \\
\text { FSH } \geq 30 \mathrm{mlU} / \mathrm{mL} \text {, } \\
\text { and } 17 \beta-E 2 \\
\leq 183.5 \mathrm{pmol} / \mathrm{L})\end{array}$ & \multirow[t]{14}{*}{$\begin{array}{l}3,544 \\
\text { OSS I: 1,454 OSS } \\
\text { ॥: } 861[12]\end{array}$} & \multirow[t]{2}{*}{$\begin{array}{l}\text { CE } \\
0.625 \mathrm{mg} / \\
\text { BZA } 10 \mathrm{mg}\end{array}$} & \multirow[t]{14}{*}{$\begin{array}{l}\text { Incidence of } \\
\text { endometrial } \\
\text { hyperplasia at } \\
1 \text { year }\end{array}$} & \multirow[t]{4}{*}{$\begin{array}{l}\text { CE } 0.45 \text { and } \\
0.625 \mathrm{mg} / \mathrm{BZA} \\
20 \text { and } 40 \mathrm{mg} \\
\text { showed low rates } \\
(<1 \%) \text { of endometrial } \\
\text { hyperplasia [9] }\end{array}$} \\
\hline & & With a uterus & & & & \\
\hline & & $\begin{array}{l}\text { No evidence of } \\
\text { endometrial hyperplasia }\end{array}$ & & \multirow{2}{*}{$\begin{array}{l}\text { CE } \\
0.625 \mathrm{mg} / \\
\text { BZA } 20 \mathrm{mg}\end{array}$} & & \\
\hline & & $\mathrm{BMI} \leq 32.2 \mathrm{~kg} / \mathrm{m}^{2}$ & & & & \\
\hline & & $\begin{array}{l}\text { OSS I: }>5 \text { YSM with a } \\
\text { baseline BMD T-score } \\
\text { between }-1 \text { and }-2.5 \\
\text { and } \geq 1 \text { additional risk } \\
\text { factor for osteoporosis } \\
{[12]}\end{array}$ & & $\begin{array}{l}\text { CE } \\
0.625 \mathrm{mg} / \\
\text { BZA } 40 \mathrm{mg}\end{array}$ & & \multirow[t]{2}{*}{$\begin{array}{l}\text { Other outcomes Incidence } \\
\text { of abnormal mammograms } \\
\text { at } 2 \text { years: } 4.4 \% \text { with } \\
\text { CE } 0.45 \mathrm{mg} / \mathrm{BZA} 20 \mathrm{mg} \text {, } \\
4.2 \% \text { with CE } 0.625 \mathrm{mg} / \mathrm{BZA} \\
20 \mathrm{mg}, 3.4 \% \text { with RLX, } \\
\text { and } 2.6 \% \text { with PBO [100] }\end{array}$} \\
\hline & & \multirow{9}{*}{$\begin{array}{l}\text { OSS II: 1-5 YSM with } \\
\geq 1 \text { risk factor for } \\
\text { Osteoporosis [12] }\end{array}$} & & & & \\
\hline & & & & $\begin{array}{l}\text { CE } 0.45 \mathrm{mg} / \\
\text { BZA } 10 \mathrm{mg}\end{array}$ & & \multirow{3}{*}{$\begin{array}{l}\text { CE } 0.625 \text { and } 0.45 \text { mg/BZA } \\
20 \text { and } 40 \text { mg associated } \\
\text { with rates of cumulative } \\
\text { amenorrhea similar to PBO } \\
(>83 \% \text { (cycles 1-13) } \\
\text { and }>93 \% \text { (cycles 10-13)); } \\
\text { bleeding and spotting } \\
\text { rates similar to PBO [11] }\end{array}$} \\
\hline & & & & $\begin{array}{l}\text { CE } 0.45 \mathrm{mg} / \\
\text { BZA } 20 \mathrm{mg}\end{array}$ & & \\
\hline & & & & $\begin{array}{l}\text { CE } 0.45 \mathrm{mg} / \\
\text { BZA } 40 \mathrm{mg}\end{array}$ & & \\
\hline & & & & \multirow[t]{5}{*}{$\begin{array}{l}\text { RLX } 60 \mathrm{mg} \\
\text { PBO }\end{array}$} & & $\begin{array}{l}\text { CE } 0.45 \text { and } 0.625 \text { mg/BZA } \\
20 \text { mg significantly reduced } \\
\text { number ( } P<0.05 \text { for both) } \\
\text { and severity }(P<0.001 \text { for } \\
\text { both) of hot flushes vs. PBO } \\
\text { at week } 12[10]\end{array}$ \\
\hline & & & & & & $\begin{array}{l}\text { CE } 0.625 \text { and } 0.45 \text { mg/BZA } \\
20 \text { mg significantly reduced } \\
\text { WA vs. PBO at month 24, } \\
\text { and } \\
\text { CE } 0.625 \text { mg/BZA } \\
20 \text { mg significantly } \\
\text { reduced the incidence } \\
\text { of dyspareunia at } \\
\text { weeks } 5-12 \text { [10] }\end{array}$ \\
\hline & & & & & & $\begin{array}{l}\text { CE } 0.45 \text { and } 0.625 \mathrm{mg} / \mathrm{BZA} \\
20 \mathrm{mg} \text { significantly improved } \\
\mathrm{LDL} \text { and } \mathrm{HDL} \text { cholesterol } \\
\text { vs. PBO ( } P<0.01 \text { for all) } \\
\text { at month } 24[10]\end{array}$ \\
\hline & & & & & & OSSs \\
\hline & & & & & & $\begin{array}{l}\text { In both OSSS, CE/BZA was } \\
\text { associated with significant } \\
\text { BMD increases at lumbar } \\
\text { spine }(P<0.001) \text { and total } \\
\text { hip }(P<0.01) \text {, with significant } \\
\text { decreases in bone turnover } \\
\text { markers [12] }\end{array}$ \\
\hline
\end{tabular}


Table 2 The SMART clinical trial program (Continued)

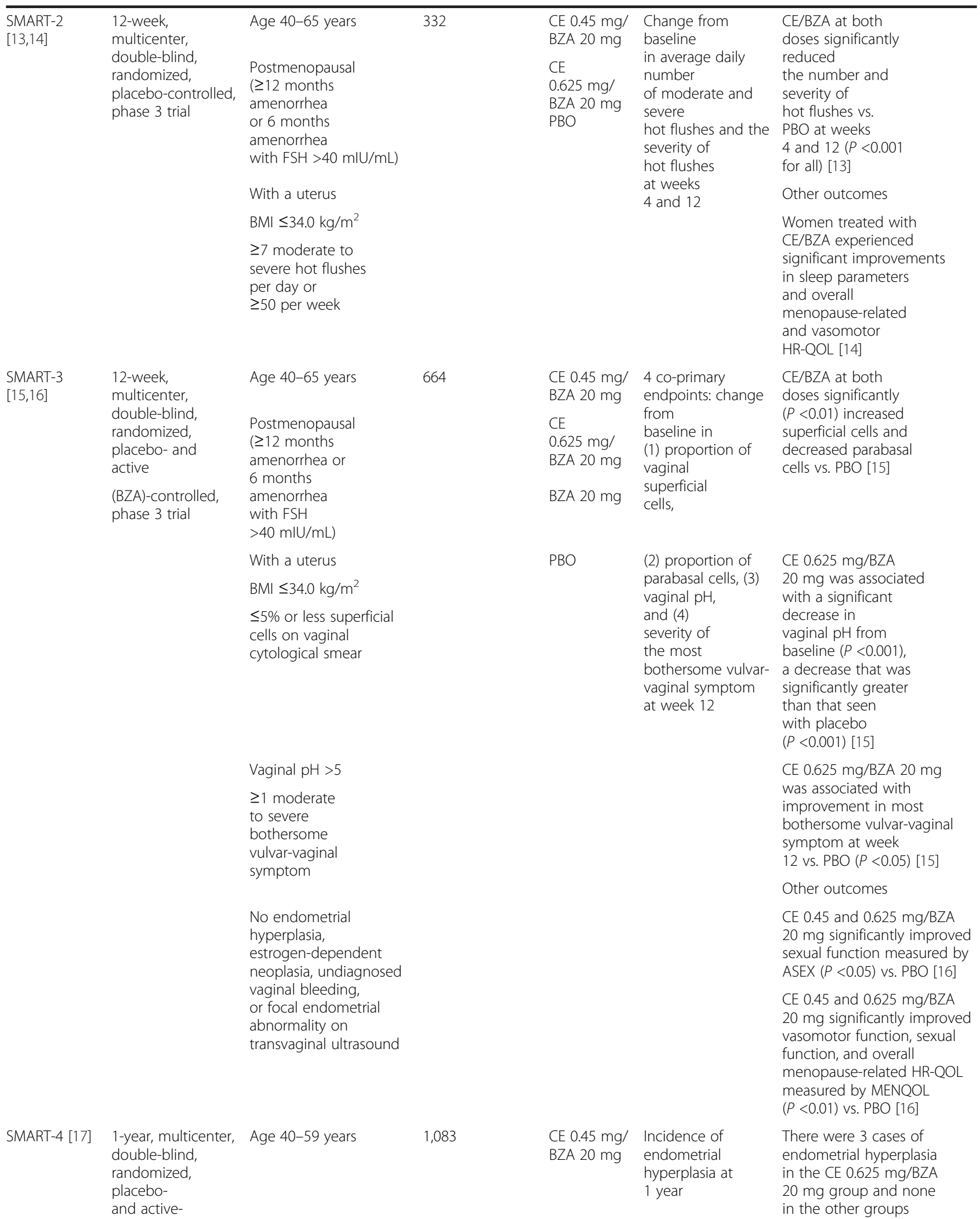


Table 2 The SMART clinical trial program (Continued)

\begin{tabular}{|c|c|c|c|c|c|c|}
\hline & $\begin{array}{l}\text { (CE/MPA) } \\
\text { controlled, } \\
\text { phase }\end{array}$ & $\begin{array}{l}\text { Postmenopausal } \\
(\geq 12 \text { months } \\
\text { amenorrhea or }\end{array}$ & & $\begin{array}{l}\text { CE } \\
0.625 \mathrm{mg} / \\
\text { BZA } 20 \mathrm{mg}\end{array}$ & $\begin{array}{l}\text { OSS: mean } \\
\text { percentage change } \\
\text { from baseline in }\end{array}$ & $\begin{array}{l}\text { All active treatments } \\
\text { produced significant } \\
\text { increases from baseline }\end{array}$ \\
\hline & & $\begin{array}{l}6 \text { months } \\
\text { amenorrhea with } \\
\text { FSH }>40 \mathrm{mlU} / \mathrm{mL} \text { ) }\end{array}$ & & $\begin{array}{l}\text { CE } 0.45 \mathrm{mg} / \\
\text { MPA } 1.5 \mathrm{mg}\end{array}$ & $\begin{array}{l}\text { lumbar spine BMD } \\
\text { at } 1 \text { year }\end{array}$ & $\begin{array}{l}\text { In lumbar spine } \\
\text { and total hip BMD } \\
\text { compared with }\end{array}$ \\
\hline & & With a uterus & & & & \\
\hline & & $\mathrm{BMI} \leq 34.0 \mathrm{~kg} / \mathrm{m}^{2}$ & & & & \\
\hline & & $\begin{array}{l}\text { No history of } \\
\text { endometrial hyperplasia } \\
\text { or undiagnosed vaginal } \\
\text { bleeding }\end{array}$ & & & & \\
\hline & & $\begin{array}{l}\text { OSS: } \leq 5 \text { years } \\
\text { amenorrhea } \\
2 \text { evaluable BMD scans } \\
\text { of lumbar spine differing } \\
\text { by } \\
<5 \% \text { and hip differing } \\
\text { by }<7.5 \%\end{array}$ & & & & \\
\hline & & $\begin{array}{l}\text { No osteoporosis or } \\
\text { fragility fractures }\end{array}$ & & & & \\
\hline SMART-5 & 1-year, multicenter, & Aged 40-65 years & 1,843 & CE $0.45 \mathrm{mg} /$ & Incidence of & Incidence of \\
\hline 1,102$]$ & double-blind, & Postmenopausal & & BZA 20 mg & endometrial & endometrial hyperplasia \\
\hline & $\begin{array}{l}\text { placebo-, } \\
\text { and active- } \\
\text { (CE/MPA) } \\
\text { controlled, }\end{array}$ & $\begin{array}{l}\text { ( } \geq 12 \text { months } \\
\text { amenorrhea or } \\
6 \text { months amenorrhea } \\
\text { with FSH }>40 \mathrm{mlU} / \mathrm{mL} \text { ) }\end{array}$ & & $\begin{array}{l}\text { CE } \\
0.625 \mathrm{mg} / \\
\text { BZA } 20 \mathrm{mg}\end{array}$ & $\begin{array}{l}\text { mean percentage } \\
\text { change in lumbar } \\
\text { spine BMD at } \\
12 \text { months }\end{array}$ & $\begin{array}{l}0.625 \mathrm{mg} / \mathrm{BZA} 20 \mathrm{mg} \\
\text { was low }(\leq 0.3 \%) \\
\text { and similar to that } \\
\text { with PBO and }\end{array}$ \\
\hline & phase 3 trial & With a uterus & & & & CE $0.45 \mathrm{mg} / \mathrm{MPA}$ \\
\hline & & $\mathrm{BMI} \leq 34.0 \mathrm{~kg} / \mathrm{m}^{2}$ & & BZA $20 \mathrm{mg}$ & & $1.5 \mathrm{mg}[102]$ \\
\hline & & $\begin{array}{l}\text { Acceptable } \\
\text { endometrial biopsy }\end{array}$ & & $\begin{array}{l}\text { CE } 0.45 \mathrm{mg} / \\
\text { MPA } 1.5 \mathrm{mg}\end{array}$ & & \\
\hline & & $\begin{array}{l}\text { Seeking treatment } \\
\text { for menopausal } \\
\text { symptoms }\end{array}$ & & PBO & & \\
\hline & & $\begin{array}{l}\text { Sleep/HR-QOL } \\
\text { substudy: bothered } \\
\text { by hot flushes/night } \\
\text { sweats plus sleep } \\
\text { interruptions }\end{array}$ & & & & $\begin{array}{l}\text { CE } 0.45 \text { and } \\
0.625 \text { mg/BZA } 20 \mathrm{mg} \\
\text { were associated } \\
\text { with significant } \\
\text { improvements } \\
\text { in lumbar spine BMD } \\
\text { vs. PBO at } 1 \text { year } \\
(P<0.001) \text { [101] }\end{array}$ \\
\hline & & & & & & Other outcomes \\
\hline & & & & & & $\begin{array}{l}\text { CE } 0.45 \text { and } 0.625 \mathrm{mg} / \mathrm{BZA} \\
20 \mathrm{mg} \text { were non-inferior to } \\
\text { PBO in percentage change } \\
\text { in mammographic breast } \\
\text { density [18] }\end{array}$ \\
\hline & & & & & & $\begin{array}{l}\text { In the sleep/HR-QOL } \\
\text { substudy, both doses of } \\
\text { CE/BZA were associated } \\
\text { with significant } \\
\text { improvements } \\
\text { in sleep parameters and } \\
\text { HRQOL at } 1 \text { year [19] }\end{array}$ \\
\hline
\end{tabular}

17ß-E2, 17ß-estradiol; ASEX, Arizona Sexual Experiences Scale; BMD, bone mineral density; BMI, body mass index; BZA, bazedoxifene; CE, conjugated estrogens; FSH, follicle-stimulating hormone; HDL, high-density lipoprotein; HR-QOL, health-related quality of life; LDL, low-density lipoprotein; MENQOL, Menopause-specific Quality of Life; MPA, medroxyprogesterone acetate; OSS, Osteoporosis Substudy; PBO, placebo; RLX, raloxifene; SMART, Selective estrogens, Menopause, And Response to Therapy; VVA, vulvar-vaginal atrophy; YSM, years since menopause. 
Table 3 Breast safety results from the SMART clinical trial program

\begin{tabular}{|c|c|c|c|c|c|}
\hline & SMART-1 & SMART-2 & SMART-3 & SMART-4 & SMART-5 \\
\hline \multirow[t]{2}{*}{$\begin{array}{l}\text { Breast pain/ } \\
\text { tenderness }\end{array}$} & \multirow[t]{2}{*}{$\begin{array}{l}\text { No significant differences } \\
\text { in incidence of breast } \\
\text { pain for any dose of } \\
\text { CE/BZA, RLX } 60 \text { mg, } \\
\text { or PBO [10] }\end{array}$} & \multirow[t]{2}{*}{$\begin{array}{l}\text { No significant } \\
\text { difference in } \\
\text { number of women } \\
\text { reporting } \geq 1 \text { day } \\
\text { of breast pain } \\
\text { between } \\
\text { CE/BZA and PBO } \\
{[13]}\end{array}$} & \multirow[t]{2}{*}{$\begin{array}{l}\text { Incidence } \\
\text { of breast } \\
\text { pain with } \\
\text { CE } 0.45 \text { mg/BZA } \\
20 \text { mg and } 0.625 \\
\text { mg/BZA } 20 \text { mg } \\
\text { not significantly } \\
\text { different from } \\
\text { PBO [15] }\end{array}$} & $\begin{array}{l}\text { No significant difference } \\
\text { in number of women } \\
\text { reporting } \geq 1 \text { day of } \\
\text { breast pain } \\
\text { between CE/BZA } \\
\text { and PBO }\end{array}$ & $\begin{array}{l}\text { Rates of breast } \\
\text { tenderness } \\
\text { with CE } 0.45 \mathrm{mg} / \mathrm{BZA} \\
20 \mathrm{mg} \\
\text { and } 0.625 \mathrm{mg} / \mathrm{BZA} \\
20 \mathrm{mg} \\
\text { from } 5.8 \%-9.4 \% \text {, } \\
\text { similar to PBO } \\
(5.4 \%-8.6 \%) \text { [18] }\end{array}$ \\
\hline & & & & $\begin{array}{l}\text { Compared with } \\
\text { CE } 0.45 \mathrm{mg} / \mathrm{MPA} 1.5 \mathrm{mg} \text {, } \\
\text { breast pain incidence } \\
\text { was significantly lower } \\
\text { with CE } 0.45 \mathrm{mg} / \mathrm{BZA} \\
20 \mathrm{mg} \text { at weeks } 5-8 \\
\text { and } 9-12(P<0.05) \text { and } \\
\text { for } \mathrm{CE} 0.625 \mathrm{mg} / \mathrm{BZA} \\
20 \mathrm{mg} \text { at weeks } 1-4 \text {, } \\
4-8, \text { and } 9-12 \\
(P<0.01)[17]\end{array}$ & $\begin{array}{l}\text { Rates of breast } \\
\text { tenderness } \\
\text { with CE } 0.45 \mathrm{mg} / \mathrm{BZA} \\
20 \mathrm{mg} \\
\text { and } 0.625 \mathrm{mg} / \mathrm{BZA} \\
20 \mathrm{mg} \\
\text { were significantly } \\
\text { lower than } \\
\text { with CE } 0.45 \mathrm{mg} / \mathrm{MPA} \\
1.5 \mathrm{mg} \\
(7.3 \%-24.3 \% \text {; } \\
P<0.001)[18]\end{array}$ \\
\hline \multirow[t]{5}{*}{$\begin{array}{l}\text { Abnormal } \\
\text { mammogram } \\
\text { findings }\end{array}$} & $\begin{array}{l}\mathrm{n}(\%) \text { at } 2 \text { years: } \\
\text { CE } 0.45 \mathrm{mg} / \mathrm{BZA} \\
20 \mathrm{mg}, 13(4.4 \%)\end{array}$ & \multirow[t]{5}{*}{ ND } & \multirow[t]{5}{*}{ ND } & \multirow[t]{5}{*}{ ND } & $\begin{array}{l}\mathrm{n}(\%) \text { at } 1 \text { year: } \\
\text { CE } 0.45 \\
\mathrm{mg} / \mathrm{BZA} 20 \mathrm{mg} \\
4(0.9 \%)\end{array}$ \\
\hline & $\begin{array}{l}\text { CE } 0.625 \mathrm{mg} / \mathrm{BZA} \\
20 \mathrm{mg}, 11(4.2 \%)\end{array}$ & & & & $\begin{array}{l}\text { CE } 0.625 \mathrm{mg} / \mathrm{BZA} \\
20 \mathrm{mg} \\
2(0.4 \%)\end{array}$ \\
\hline & RLX 60 mg, 9 (3.4\%) & & & & BZA 20 mg, 1 (0.4\%) \\
\hline & \multirow[t]{2}{*}{ PBO, 7 (2.6\%) [100] } & & & & $\begin{array}{l}\text { CE } 0.45 \mathrm{mg} / \mathrm{MPA} \\
1.5 \mathrm{mg} \\
3(1.4 \%)\end{array}$ \\
\hline & & & & & PBO, 1 (0.2\%) [18] \\
\hline \multirow[t]{8}{*}{$\begin{array}{l}\text { Breast density } \\
\text { changes }\end{array}$} & $\begin{array}{l}\text { No significant } \\
\text { differences between } \\
\text { groups in breast } \\
\text { density }\end{array}$ & \multirow[t]{8}{*}{ ND } & \multirow[t]{8}{*}{ ND } & \multirow[t]{8}{*}{ ND } & \multirow{2}{*}{$\begin{array}{l}\text { No significant } \\
\text { differences from PBO } \\
\text { with CE } 0.45 \\
\text { mg/BZA } 20 \text { mg or } \\
0.625 \text { mg/BZA } 20 \text { mg; } \\
\text { CE } 0.45 \text { mg/MPA } \\
1.5 \text { mg significantly } \\
\text { increased breast } \\
\text { density vs. PBO } \\
(P<0.001)\end{array}$} \\
\hline & $\begin{array}{l}\text { Mean (SD) percentage change from } \\
\text { baseline in percentage breast density } \\
\text { at } 2 \text { years: CE } 0.45 \mathrm{mg} / \mathrm{BZA} 20 \mathrm{mg} \text {, } \\
-0.39 \%(1.75 \%)\end{array}$ & & & & \\
\hline & $\begin{array}{l}\text { CE } 0.625 \mathrm{mg} / \mathrm{BZZA} 20 \mathrm{mg},-0.05 \% \\
(1.68 \%)\end{array}$ & & & & \multirow{2}{*}{$\begin{array}{l}\text { Adjusted percentage } \\
\text { change from baseline } \\
\text { in percentage breast } \\
\text { density } \\
\text { at } 1 \text { year, mean (SD): } \\
\text { CE } 0.45 \mathrm{mg} / \mathrm{BZA} \\
20 \mathrm{mg} \text {, } \\
-0.38 \%(0.22 \%)\end{array}$} \\
\hline & RLX 60 mg, $-0.23 \%$ (1.76\%) & & & & \\
\hline & \multirow[t]{4}{*}{$\mathrm{PBO},-0.42 \%(1.72 \%)[100]$} & & & & $\begin{array}{l}\text { CE } 0.625 \mathrm{mg} / \mathrm{BZA} \\
20 \mathrm{mg},-0.44 \%(0.22 \%)\end{array}$ \\
\hline & & & & & $\begin{array}{l}\text { BZA } 20 \mathrm{mg},-0.24 \% \\
(0.30 \%)\end{array}$ \\
\hline & & & & & $\begin{array}{l}\text { CE } 0.45 \text { mg/MPA } \\
1.5 \mathrm{mg}, 1.60 \%(0.35 \%)\end{array}$ \\
\hline & & & & & $\begin{array}{l}\mathrm{PBO},-0.32 \%(0.23 \%) \\
{[18]}\end{array}$ \\
\hline
\end{tabular}


[18]. Thus, the clinical data support the favorable breastrelated safety and tolerability profile of $\mathrm{CE} / \mathrm{BZA}$ in postmenopausal women with a uterus.

\section{Conclusions}

A number of available treatments provide effective relief of VMS and VVA along with prevention of postmenopausal osteoporosis, but new options with improved breast-related safety and tolerability are needed. Results from large randomized and observational studies have shown an association between HT, particularly EPT, and increased risk of breast cancer [6-8]. HT use by postmenopausal women has been associated with increased mammographic breast density [21,22], which is a risk factor for breast cancer $[38,39]$. Breast pain and tenderness are also a concern with HT.

SERMs are generally well tolerated and have demonstrated positive effects on the breast but do not relieve menopausal symptoms. A TSEC aims to take advantage of the positive effects of both the SERM and the estrogen components to treat menopausal symptoms and prevent postmenopausal osteoporosis without stimulating the breast or endometrium. Strong preclinical evidence supports the breast safety of CE/BZA. Clinically, CE/BZA has shown no or minimal increased risk of breast effects, and the results of phase 3 clinical trials have demonstrated a favorable breast-related safety and tolerability profile in non-hysterectomized postmenopausal women. Additional studies are necessary to elucidate the effects, if any, of HT, SERMs, and TSECs on occult pre-existing breast tumors.

\section{Abbreviations \\ BMD: Bone mineral density; BZA: Bazedoxifene; CE: Conjugated estrogen; CORE: Continuing Outcomes Relevant to Evista; EPT: Estrogen-progestin therapy; ER: Estrogen receptor; ET: Estrogen therapy; EU: European Union; HR: Hazard ratio; HT: Hormone therapy; LAS: Lasofoxifene; MORE: Multiple outcomes of raloxifene evaluation; MPA: Medroxyprogesterone acetate; OVX: Ovariectomized; PBO: Placebo; R: Progesterone receptor; RLX: Raloxifene; RR: Relative risk; SERM: Selective estrogen receptor modulator; SMART: Selective estrogens, menopause, and response to therapy; TSEC: Tissue-selective estrogen complex; VMS: Vasomotor symptom; WA: Vulvar-vaginal atrophy; WHI: Women's Health Initiative.}

\section{Competing interests}

BK is a full-time employee of Pfizer. SM was a full-time employee of Pfizer at the time of manuscript development. RJS serves on an advisory board for Pfizer; is a consultant for Pfizer, Teva (Petah Tikva, Central District, Israel), and Novo Nordisk (Bagsvaerd, Denmark); and has received a grant from Pfizer to study the in vitro and in vivo effects of TSECS. CLS serves on an advisory board for Pfizer and has received research funding from Pfizer.

\section{Authors' contributions}

All authors were involved in drafting the manuscript or critically revising it for important intellectual content and have read and approved the final manuscript.

\section{Acknowledgments}

Medical writing assistance for the manuscript was provided by Staci Heise, of MedErgy (Morrisville, PA, USA), and by Diane M Sloan, of Peloton Advantage (Parsippany, NJ, USA), both of whom were funded by Pfizer. The authors are responsible for the scientific content.

\section{Author details}

'Molecular and Cellular Biology, Baylor College of Medicine, One Baylor Plaza, Houston, TX 77030, USA. ${ }^{2}$ University of Virginia School of Medicine, 450 Ray C. Hunt Drive, Fontaine Research Park, Charlottesville, VA 22908, USA. ${ }^{3}$ Pfizer Inc, 500 Arcola Road, Collegeville, PA 19426, USA.

Published: 18 Jun 2014

\section{References}

1. Williams RE, Kalilani L, DiBenedetti DB, Zhou X, Granger AL, Fehnel SE, Levine KB, Jordan J, Clark RV: Frequency and severity of vasomotor symptoms among peri- and postmenopausal women in the United States. Climacteric 2008, 11:32-43.

2. Mac Bride MB, Rhodes DJ, Shuster LT: Vulvovaginal atrophy. Mayo Clin Proc 2010, 85:87-94.

3. Riggs BL, Khosla S, Melton $L \mathrm{III}: \mathrm{A}$ unitary model for involutional osteoporosis: estrogen deficiency causes both type I and type II osteoporosis in postmenopausal women and contributes to bone loss in aging men. J Bone Miner Res 1998, 13:763-773.

4. National Osteoporosis Foundation: What women need to know. http://www.nof.org/articles/235.

5. The 2012 hormone therapy position statement of The North American Menopause Society. Menopause 2012, 19:257-271

6. Chen WY, Manson JE, Hankinson SE, Rosner B, Holmes MD, Willett WC, Colditz GA: Unopposed estrogen therapy and the risk of invasive breast cancer. Arch Intern Med 2006, 166:1027-1032.

7. Barnabei VM, Cochrane BB, Aragaki AK, Nygaard I, Williams RS, McGovern PG, Young RL, Wells EC, O'Sullivan MJ, Chen B, Schenken R, Johnson SR: Menopausal symptoms and treatment-related effects of estrogen and progestin in the Women's Health Initiative. Obstet Gynecol 2005, 105:1063-1073.

8. Chlebowski RT, Hendrix SL, Langer RD, Stefanick ML, Gass M, Lane D, Rodabough RJ, Gilligan MA, Cyr MG, Thomson CA, Khandekar J, Petrovitch H, McTiernan A: Influence of estrogen plus progestin on breast cancer and mammography in healthy postmenopausal women: the Women's Health Initiative Randomized Trial. JAMA 2003, 289:3243-3253.

9. Pickar JH, Yeh IT, Bachmann G, Speroff L: Endometrial effects of a tissue selective estrogen complex containing bazedoxifene/conjugated estrogens as a menopausal therapy. Fertil Steril 2009, 92:1018-1024.

10. Lobo RA, Pinkerton JV, Gass ML, Dorin MH, Ronkin S, Pickar JH, Constantine $\mathrm{G}$ : Evaluation of bazedoxifene/conjugated estrogens for the treatment of menopausal symptoms and effects on metabolic parameters and overall safety profile. Fertil Steril 2009, 92:1025-1038.

11. Archer DF, Lewis V, Carr BR, Olivier S, Pickar JH: Bazedoxifene/conjugated estrogens (BZA/CE): incidence of uterine bleeding in postmenopausal women. Fertil Steril 2009, 92:1039-1044.

12. Lindsay R, Gallagher JC, Kagan R, Pickar JH, Constantine G: Efficacy of tissue-selective estrogen complex of bazedoxifene/conjugated estrogens for osteoporosis prevention in at-risk postmenopausal women. Fertil Steril 2009, 92:1045-1052.

13. Pinkerton JV, Utian WH, Constantine GD, Olivier S, Pickar JH: Relief of vasomotor symptoms with the tissue-selective estrogen complex containing bazedoxifene/ conjugated estrogens: a randomized, controlled trial. Menopause 2009, 16:1116-1124.

14. Utian W, Yu H, Bobula J, Mirkin S, Olivier S, Pickar JH: Bazedoxifene/ conjugated estrogens and quality of life in postmenopausal women. Maturitas 2009, 63:329-335.

15. Kagan R, Williams RS, Pan K, Mirkin S, Pickar JH: A randomized, placebo- and active-controlled trial of bazedoxifene/conjugated estrogens for treatment of moderate to severe vulvar/vaginal atrophy in postmenopausal women. Menopause 2010, 17:281-289.

16. Bachmann G, Bobula J, Mirkin S: Effects of bazedoxifene/conjugated estrogens on quality of life in postmenopausal women with symptoms of vulvar/vaginal atrophy. Climacteric 2010, 13:132-140.

17. Mirkin S, Komm BS, Pan K, Chines AA: Effects of bazedoxifene/conjugated estrogens on endometrial safety and bone in postmenopausal women. Climacteric 2013, 16:338-346.

18. Pinkerton JV, Harvey JA, Pan K, Thompson JR, Ryan KA, Chines AA, Mirkin S: Breast effects of bazedoxifene-conjugated estrogens: a randomized controlled trial. Obstet Gynecol 2013, 121:959-968. 
19. Pinkerton JV, Pan K, Abraham L, Racketa J, Ryan KA, Chines AA, Mirkin S: Sleep parameters and health-related quality of life with bazedoxifene/ conjugated estrogens: a randomized trial. Menopause 2014, 21:252-259.

20. Pinkerton JV, Harvey JA, Lindsay R, Pan K, Chines AA, Mirkin S, Archer DF: Effects of bazedoxifene/conjugated estrogens on the endometrium and bone: a randomized trial. J Clin Endocrinol Metab 2014, 99:E189-E198.

21. Crandall CJ, Aragaki AK, Cauley JA, MCTiernan A, Manson JE, Anderson GL, Wactawski-Wende J, Chlebowski RT: Breast tenderness after initiation of conjugated equine estrogens and mammographic density change. Breast Cancer Res Treat 2012, 131:969-979.

22. MCTiernan A, Martin CF, Peck JD, Aragaki AK, Chlebowski RT, Pisano ED, Wang CY, Brunner RL, Johnson KC, Manson JE, Lewis CE, Kotchen JM, Hulka BS: Estrogen-plus-progestin use and mammographic density in postmenopausal women: Women's Health Initiative randomized trial. J Natl Cancer Inst 2005, 97:1366-1376

23. Anderson GL, Limacher M, Assaf AR, Bassford T, Beresford SA, Black H, Bonds D, Brunner R, Brzyski R, Caan B, Chlebowski R, Curb D, Gass M, Hays J, Heiss G, Hendrix S, Howard BV, Hsia J, Hubbell A, Jackson R, Johnson KC, Judd H, Kotchen JM, Kuller L, LaCroix AZ, Lane D, Langer RD, Lasser N, Lewis CE, Manson J, et al: Effects of conjugated equine estrogen in postmenopausal women with hysterectomy: the Women's Health Initiative randomized controlled trial. JAMA 2004, 291:1701-1712.

24. Anderson $\mathrm{GL}$, Chlebowski RT, Aragaki AK, Kuller LH, Manson JE, Gass M, Bluhm E, Connelly S, Hubbell FA, Lane D, Martin L, Ockene J, Rohan T, Schenken R, Wactawski-Wende J: Conjugated equine oestrogen and breast cancer incidence and mortality in postmenopausal women with hysterectomy: extended follow-up of the Women's Health Initiative randomised placebo-controlled trial. Lancet Oncol 2012, 13:476-486.

25. Chlebowski RT, Anderson GL, Gass M, Lane DS, Aragaki AK, Kuller LH, Manson JE, Stefanick ML, Ockene J, Sarto GE, Johnson KC, Wactawski-Wende J, Ravdin PM, Schenken R, Hendrix SL, Rajkovic A, Rohan TE, Yasmeen S, Prentice RL: Estrogen plus progestin and breast cancer incidence and mortality in postmenopausal women. JAMA 2010, 304:1684-1692.

26. Kenemans $P$, Bosman A: Breast cancer and post-menopausal hormone therapy. Best Pract Res Clin Endocrinol Metab 2003, 17:123-137.

27. Santen RJ, Yue W, Heitjan DF: Modeling of the growth kinetics of occult breast tumors: role in interpretation of studies of prevention and menopausal hormone therapy. Cancer Epidemiol Biomarkers Prev 2012, 21:1038-1048

28. Cavalieri EL, Stack DE, Devanesan PD, Todorovic R, Dwivedy I, Higginbotham S, Johansson SL, Patil KD, Gross ML, Gooden JK, Ramanathan R, Cerny RL, Rogan EG: Molecular origin of cancer: catechol estrogen-3,4-quinones as endogenous tumor initiators. Proc Natl Acad Sci U S A 1997, 94:10937-10942

29. Song Y, Santen RJ, Wang JP, Yue W: Inhibitory effects of a bazedoxifene/ conjugated equine estrogen combination on human breast cancer cells in vitro. Endocrinology 2013, 154:656-665.

30. Song Y, Santen RJ, Wang JP, Yue W: Effects of the conjugated equine estrogen/bazedoxifene tissue-selective estrogen complex (TSEC) on mammary gland and breast cancer in mice. Endocrinology 2012, 153:5706-5715.

31. Obr AE, Edwards DP: The biology of progesterone receptor in the normal mammary gland and in breast cancer. Mol Cell Endocrinol 2012, 357:4-17.

32. Axlund SD, Sartorius CA: Progesterone regulation of stem and progenitor cells in normal and malignant breast. Mol Cell Endocrinol 2012, 357:71-79.

33. Liang Y, Benakanakere I, Besch-Williford C, Hyder RS, Ellersieck MR, Hyder SM: Synthetic progestins induce growth and metastasis of BT-474 human breast cancer xenografts in nude mice. Menopause 2010, 17:1040-1047.

34. Tkach M, Rosemblit C, Rivas MA, Proietti CJ, Diaz Flaque MC, Mercogliano MF, Beguelin W, Maronna E, Guzman P, Gercovich FG, Deza EG, Elizalde PV, Schillaci R: p42/p44 MAPK-mediated Stat3Ser727 phosphorylation is required for progestin-induced full activation of Stat3 and breast cancer growth. Endocr Relat Cancer 2013, 20:197-212.

35. Brisken C: Progesterone signalling in breast cancer: a neglected hormone coming into the limelight. Nat Rev Cancer 2013, 13:385-396.

36. Rivas MA, Venturutti L, Huang YW, Schillaci R, Huang TH, Elizalde PV: Downregulation of the tumor-suppressor miR-16 via progestin-mediated oncogenic signaling contributes to breast cancer development. Breast Cancer Res 2012, 14:R77.

37. Lopez Perez FR, Liang Y, Besch-Williford CL, Mafuvadze B, Hyder SM: Differential expression of FGF family members in a progestin-dependent BT-474 human breast cancer xenograft model. Histol Histopathol 2012, 27:337-345.
38. Boyd NF, Rommens JM, Vogt K, Lee V, Hopper JL, Yaffe MJ, Paterson AD: Mammographic breast density as an intermediate phenotype for breast cancer. Lancet Oncol 2005, 6:798-808.

39. McCormack VA, dos Santos SI: Breast density and parenchymal patterns as markers of breast cancer risk: a meta-analysis. Cancer Epidemiol Biomarkers Prev 2006, 15:1159-1169.

40. Carney PA, Miglioretti DL, Yankaskas BC, Kerlikowske K, Rosenberg R, Rutter CM, Geller BM, Abraham LA, Taplin SH, Dignan M, Cutter G, Ballard-Barbash R: Individual and combined effects of age, breast density, and hormone replacement therapy use on the accuracy of screening mammography. Ann Intern Med 2003, 138:168-175.

41. Crandall CJ, Aragaki AK, Cauley JA, McTiernan A, Manson JE, Anderson G, Chlebowski RT: Breast tenderness and breast cancer risk in the estrogen plus progestin and estrogen-alone women's health initiative clinical trials. Breast Cancer Res Treat 2012, 132:275-285.

42. Riggs BL, Hartmann LC: Selective estrogen-receptor modulators - mechanisms of action and application to clinical practice. N Engl J Med 2003, 348:618-629.

43. Pickar JH, MacNeil T, Ohleth K: SERMs: progress and future perspectives. Maturitas 2010, 67:129-138.

44. Jordan VC, Morrow M: Tamoxifen, raloxifene, and the prevention of breast cancer. Endocr Rev 1999, 20:253-278.

45. Jordan VC, Phelps E, Lindgren JU: Effects of anti-estrogens on bone in castrated and intact female rats. Breast Cancer Res Treat 1987, 10:31-35.

46. Turner $\mathrm{CH}$, Sato $\mathrm{M}, \mathrm{Bryant} \mathrm{HU}$ : Raloxifene preserves bone strength and bone mass in ovariectomized rats. Endocrinology 1994, 135:2001-2005.

47. Love RR, Mazess RB, Barden HS, Epstein S, Newcomb PA, Jordan VC, Carbone PP, DeMets DL: Effects of tamoxifen on bone mineral density in postmenopausal women with breast cancer. N Engl J Med 1992, 326:852-856.

48. Kedar RP, Bourne TH, Powles TJ, Collins WP, Ashley SE, Cosgrove DO, Campbell S: Effects of tamoxifen on uterus and ovaries of postmenopausal women in a randomised breast cancer prevention trial. Lancet 1994, 343:1318-1321.

49. Maximov PY, Lee TM, Jordan VC: The discovery and development of selective estrogen receptor modulators (SERMs) for clinical practice. Curr Clin Pharmacol 2013, 8:135-155.

50. Goldstein SR, Bhattoa HP, Neven P, Cox DA, Dowsett SA, Alam J, Sipos A, Muram D: Gynecologic effects of arzoxifene in postmenopausal women with osteoporosis or low bone mass. Menopause 2012, 19:41-47.

51. Cummings SR, McClung M, Reginster JY, Cox D, Mitlak B, Stock J, AmewouAtisso M, Powles T, Miller P, Zanchetta J, Christiansen C: Arzoxifene for prevention of fractures and invasive breast cancer in postmenopausal women. J Bone Miner Res 2011, 26:397-404.

52. Powles TJ, Diem SJ, Fabian CJ, Neven P, Wickerham DL, Cox DA, Muram D, Agnusdei D, Dowsett SA, Amewou-Atisso M, Cummings SR: Breast cancer incidence in postmenopausal women with osteoporosis or low bone mass using arzoxifene. Breast Cancer Res Treat 2012, 134:299-306.

53. Osphena [package insert]. Florham Park, NJ: Shionogi Inc; 2013.

54. Nolvadex [package insert]. Wilmington, DE: AstraZeneca Pharmaceuticals LP: 2005.

55. Jordan VC: Effect of tamoxifen (ICI 46,474) on initiation and growth of DMBA-induced rat mammary carcinomata. Eur J Cancer 1976, 12:419-424.

56. Shafie SM, Grantham FH: Role of hormones in the growth and regression of human breast cancer cells (MCF-7) transplanted into athymic nude mice. J Natl Cancer Inst 1981, 67:51-56.

57. Shelly W, Draper MW, Krishnan V, Wong M, Jaffe RB: Selective estrogen receptor modulators: an update on recent clinical findings. Obstet Gynecol Surv 2008, 63:163-181.

58. Chow CK, Venzon D, Jones EC, Premkumar A, O'Shaughnessy J, Zujewski J: Effect of tamoxifen on mammographic density. Cancer Epidemiol Biomarkers Prev 2000, 9:917-921.

59. Cuzick J, Warwick J, Pinney E, Duffy SW, Cawthorn S, Howell A, Forbes JF, Warren RM: Tamoxifen-induced reduction in mammographic density and breast cancer risk reduction: a nested case-control study. J Nat/ Cancer Inst 2011, 103:744-752.

60. Evista [package insert]. Indianapolis, IN: Eli Lilly and Company; 2011.

61. Komm BS, Kharode YP, Bodine PV, Harris HA, Miller CP, Lyttle CR: Bazedoxifene acetate: a selective estrogen receptor modulator with improved selectivity. Endocrinology 2005, 146:3999-4008.

62. Chang KC, Wang Y, Bodine PV, Nagpal S, Komm BS: Gene expression profiling studies of three SERMs and their conjugated estrogen combinations in human breast cancer cells: insights into the unique 
antagonistic effects of bazedoxifene on conjugated estrogens. J Steroid Biochem Mol Biol 2010, 118:117-124.

63. Lewis-Wambi JS, Kim H, Curpan R, Grigg R, Sarker MA, Jordan VC: The selective estrogen receptor modulator bazedoxifene inhibits hormone-independent breast cancer cell growth and down-regulates estrogen receptor alpha and cyclin D1. Mol Pharmacol 2011, 80:610-620.

64. Crabtree JS, Peano BJ, Zhang X, Komm BS, Winneker RC, Harris HA: Activity of three selective estrogen receptor modulators on hormone-dependent responses in the mouse uterus and mammary gland. Mol Cell Endocrinol 2008, 287:40-46.

65. Cauley JA, Norton L, Lippman ME, Eckert S, Krueger KA, Purdie DW, Farrerons J, Karasik A, Mellstrom D, Ng KW, Stepan JJ, Powles TJ, Morrow M, Costa A, Silfen SL, Walls EL, Schmitt H, Muchmore DB, Jordan VC, Ste-Marie LG: Continued breast cancer risk reduction in postmenopausal women treated with raloxifene: 4-year results from the MORE trial. Multiple outcomes of raloxifene evaluation. Breast Cancer Res Treat 2001, 65:125-134.

66. Martino S, Cauley JA, Barrett-Connor E, Powles TJ, Mershon J, Disch D, Secrest RJ, Cummings SR: Continuing outcomes relevant to Evista: breast cancer incidence in postmenopausal osteoporotic women in a randomized trial of raloxifene. J Natl Cancer Inst 2004, 96:1751-1761.

67. Barrett-Connor E, Mosca L, Collins P, Geiger MJ, Grady D, Kornitzer M, McNabb MA, Wenger NK: Effects of raloxifene on cardiovascular events and breast cancer in postmenopausal women. N Engl J Med 2006, 355:125-137.

68. Vogel VG, Costantino JP, Wickerham DL, Cronin WM, Cecchini RS, Atkins JN, Bevers TB, Fehrenbacher L, Pajon ER, Wade JL III, Robidoux A, Margolese RG, James J, Runowicz CD, Ganz PA, Reis SE, McCaskill-Stevens W, Ford LG, Jordan VC, Wolmark N: Update of the National Surgical Adjuvant Breast and Bowel Project Study of Tamoxifen and Raloxifene (STAR) P-2 Trial: preventing breast cancer. Cancer Prev Res (Phila) 2010, 3:696-706.

69. Voss S, Quail D, Dawson A, Backstrom T, Aguas F, Erenus M, The HS, Bonnar J, De GC, Hunter M, Nickelsen T: A randomised, double-blind trial comparing raloxifene $\mathrm{HCl}$ and continuous combined hormone replacement therapy in postmenopausal women: effects on compliance and quality of life. BJOG 2002, 109:874-885.

70. Pearman L, Kagan R, Arsenault J, Muram D: The effects of raloxifene on mammographic breast density: a review of clinical trials. Menopause 2010, 17:654-659.

71. Freedman M, San MJ, O'Gorman J, Eckert S, Lippman ME, Lo SC, Walls EL, Zeng J: Digitized mammography: a clinical trial of postmenopausal women randomly assigned to receive raloxifene, estrogen, or placebo. J Natl Cancer Inst 2001, 93:51-56.

72. Jackson VP, San Martin JA, Secrest RJ, McNabb M, Carranza-Lira S, Fiqueroa-Casas $P$, Fernandes CE, Romaguera J: Comparison of the effect of raloxifene and continuous-combined hormone therapy on mammographic breast density and breast tenderness in postmenopausal women. Am J Obstet Gynecol 2003, 188:389-394.

73. Eilertsen AL, Karssemeijer N, Skaane P, Qvigstad E, Sandset PM: Differential impact of conventional and low-dose oral hormone therapy, tibolone and raloxifene on mammographic breast density, assessed by an automated quantitative method. BJOG 2008, 115:773-779.

74. Gennari L: Lasofoxifene, a new selective estrogen receptor modulator for the treatment of osteoporosis and vaginal atrophy. Expert Opin Pharmacother 2009, 10:2209-2220.

75. Rosati RL, Da Silva JP, Cameron KO, Thompson DD, Ke HZ, Toler SM, Brown TA, Pan LC, Ebbinghaus CF, Reinhold AR, Elliott NC, Newhouse BN, Tjoa CM, Sweetnam PM, Cole MJ, Arriola MW, Gauthier JW, Crawford DT, Nickerson DF, Pirie CM, Qi H, Simmons HA, Tkalcevic GT: Discovery and preclinical pharmacology of a novel, potent, nonsteroidal estrogen receptor agonist/ antagonist, CP-336156, a diaryltetrahydronaphthalene. J Med Chem 1998, 41:2928-2931.

76. Cline JM, Botts S, Lees CJ, Brommage R: Effects of lasofoxifene on the uterus, vagina, and breast in ovariectomized cynomolgus monkeys (Macaca fascicularis). Am J Obstet Gynecol 2008, 199:158.

77. LaCroix AZ, Powles T, Osborne CK, Wolter K, Thompson JR, Thompson DD, Allred DC, Armstrong R, Cummings SR, Eastell R, Ensrud KE, Goss P, Lee A, Neven P, Reid DM, Curto M, Vukicevic S: Breast cancer incidence in the randomized PEARL trial of lasofoxifene in postmenopausal osteoporotic women. J Natl Cancer Inst 2010, 102:1706-1715.
78. Davidson M, Moffett A, Welty F, Simon J, Bolognese M, de Melo N, Wolter K, Proulx J, Radecki D: Extraskeletal effects of lasofoxifene on postmenopausal women [abstract SA428]. J Bone Miner Res 2005, 20(suppl 1):S173.

79. Fablyn ${ }^{\circledast}$. Ligand. http://www.ligand.com/fablyn.

80. Ligand inks week's second lasofoxifene licensing deal. Genet Eng Biotechnol News. http://www.genengnews.com/gen-news-highlights/ligand-inks-week-s-secondlasofoxifene-licensing-deal/81248637/.

81. Miller PD, Chines AA, Christiansen C, Hoeck HC, Kendler DL, Lewiecki EM, Woodson G, Levine AB, Constantine G, Delmas PD: Effects of bazedoxifene on BMD and bone turnover in postmenopausal women: 2-yr results of a randomized, double-blind, placebo-, and active-controlled study. J Bone Miner Res 2008, 23:525-535.

82. Silverman SL, Christiansen C, Genant HK, Vukicevic S, Zanchetta JR, de Villiers TJ, Constantine GD, Chines AA: Efficacy of bazedoxifene in reducing new vertebral fracture risk in postmenopausal women with osteoporosis: results from a 3-year, randomized, placebo-, and active-controlled clinical trial. J Bone Miner Res 2008, 23:1923-1934.

83. Komm BS, Lyttle CR: Developing a SERM: stringent preclinical selection criteria leading to an acceptable candidate (WAY-140424) for clinical evaluation. Ann N Y Acad Sci 2001, 949:317-326.

84. Santen RJ, Kagan R, Altomare CJ, Komm B, Mirkin S, Taylor HS: Current and evolving approaches to individualizing estrogen receptor-based therapy approaches for menopausal women. J Clin Endocrinol Metab 2014, 99:733-747.

85. Mirkin S, Archer DF, Taylor HS, Pickar JH, Komm BS: Differential effects of menopausal therapies on the endometrium. Menopause 2014, [Epub ahead of print].

86. Wardell SE, Nelson ER, Chao CA, McDonnell DP: Bazedoxifene exhibits antiestrogenic activity in animal models of tamoxifen-resistant breast cancer: implications for treatment of advanced disease. Clin Cancer Res 2013, 19:2420-2431.

87. Pinkerton JV, Archer DF, Utian WH, Menegoci JC, Levine AB, Chines AA, Constantine GD: Bazedoxifene effects on the reproductive tract in postmenopausal women at risk for osteoporosis. Menopause 2009, 16:1102-1108.

88. Archer DF, Pinkerton JV, Utian WH, Menegoci JC, de Villiers TJ, Yuen CK, Levine $A B$, Chines AA, Constantine GD: Bazedoxifene, a selective estrogen receptor modulator: effects on the endometrium, ovaries, and breast from a randomized controlled trial in osteoporotic postmenopausal women. Menopause 2009, 16:1109-1115.

89. Christiansen C, Chesnut CH III, Adachi JD, Brown JP, Fernandes CE, Kung AW, Palacios S, Levine AB, Chines AA, Constantine GD: Safety of bazedoxifene in a randomized, double-blind, placebo- and active-controlled phase 3 study of postmenopausal women with osteoporosis. BMC Musculoskelet Disord 2010, 11:130.

90. Harvey JA, Holm MK, Ranganath R, Guse PA, Trott EA, Helzner E: The effects of bazedoxifene on mammographic breast density in postmenopausal women with osteoporosis. Menopause 2009, 16:1193-1196.

91. de Villiers TJ, Chines AA, Palacios S, Lips P, Sawicki AZ, Levine AB, Codreanu C, Kelepouris N, Brown JP: Safety and tolerability of bazedoxifene in postmenopausal women with osteoporosis: results of a 5-year, randomized, placebo-controlled phase 3 trial. Osteoporos Int 2011, 22:567-576.

92. Palacios $S$, de Villiers TJ, Nardone FC, Levine AB, Williams R, Hines T, Mirkin S, Chines AA: Assessment of the safety of long-term bazedoxifene treatment on the reproductive tract in postmenopausal women with osteoporosis: results of a 7-year, randomized, placebo-controlled, phase 3 study. Maturitas 2013, 76:81-87.

93. Kharode Y, Bodine PV, Miller CP, Lyttle CR, Komm BS: The pairing of a selective estrogen receptor modulator, bazedoxifene, with conjugated estrogens as a new paradigm for the treatment of menopausal symptoms and osteoporosis prevention. Endocrinology 2008, 149:6084-6091.

94. de Villiers TJ, Pines A, Panay N, Gambacciani M, Archer DF, Baber RJ, Davis SR, Gompel AA, Henderson WW, Langer R, Lobo RA, Plu-Bureau, Sturdee DW: Updated 2013 International Menopause Society recommendations on menopausal hormone therapy and preventive strategies for midlife health. Climacteric 2013, 16:316-337.

95. Liu S, Han SJ, Smith CL: Cooperative activation of gene expression by agonists and antagonists mediated by estrogen receptor heteroligand dimer complexes. Mol Pharmacol 2013, 83:1066-1077.

96. Wardell SE, Kazmin D, McDonnell DP: Research resource: transcriptional profiling in a cellular model of breast cancer reveals functional and mechanistic differences between clinically relevant SERM and between SERM/estrogen complexes. Mol Endocrinol 2012, 26:1235-1248. 
97. Berrodin TJ, Chang KC, Komm BS, Freedman LP, Nagpal S: Differential biochemical and cellular actions of Premarin estrogens: distinct pharmacology of bazedoxifene-conjugated estrogens combination. Mol Endocrinol 2009, 23:74-85.

98. Peano BJ, Crabtree JS, Komm BS, Winneker RC, Harris HA: Effects of various selective estrogen receptor modulators with or without conjugated estrogens on mouse mammary gland. Endocrinology 2009, 150:1897-1903.

99. Ethun KF, Wood CE, Register TC, Cline JM, Appt SE, Clarkson TB: Effects of bazedoxifene acetate with and without conjugated equine estrogens on the breast of postmenopausal monkeys. Menopause 2012, 19:1242-1252.

100. Harvey JA, Pinkerton JV, Baracat EC, Shi H, Chines AA, Mirkin S: Breast density changes in a randomized controlled trial evaluating bazedoxifene/conjugated estrogens. Menopause 2013, 20:138-145.

101. Gallagher JC, Lindsay R, Pan K, Mirkin S, Chines A: Effects of bazedoxifene/ conjugated estrogens on bone mineral density and bone turnover markers in postmenopausal women: a double-blind, randomized, placebo- and activecontrolled phase 3 study [abstract 1133]. J Bone Miner Res 2011, 26(suppl 1):S46.

102. Archer DF, Lobo RA, Pan K, Chines AA, Mirkin S: Safety and tolerability of bazedoxifene/conjugated estrogens in postmenopausal women: findings from a 1-year, randomized, placebo- and active-controlled, phase 3 trial [abstract P-25]. Menopause 2011, 18:1355-1356.

103. Duavee [package insert]. Philadelphia, PA: Wyeth Pharmaceuticals Inc. a subsidiary of Pfizer Inc; 2013.

104. Pinkerton JV, Taylor H, Pan K, Chines A: Breast parameters with bazedoxifene/conjugated estrogens in randomized, controlled trials of postmenopausal women [abstract]. Menopause 2010, 17:1221-1222.

$10.1186 /$ bcr3677

Cite this article as: Smith et al:: Breast-related effects of selective estrogen receptor modulators and tissue-selective estrogen complexes. Breast Cancer Research 2014, 16:212 